JISHENG XIA, Ph.D. ${ }^{1}$

E-mail: xiajsh@ynu.edu.cn

PINLIANG DONG, Ph.D. ${ }^{2}$

E-mail: Pinliang.Dong@unt.edu

ZHIFANG ZHAO, Ph.D. ${ }^{1}$

(Corresponding author)

E-mail: zzf_1002@163.com

${ }^{1}$ School of Earth Sciences, Yunnan University

Chenggong, Kunming, Yunnan 650500, China

${ }^{2}$ Department of Geography and the Environment

University of North Texas

1155 Union Circle, \#305279, Denton, TX 76203, USA
Traffic Infrastructure

Preliminary Communication

Submitted: 2 May 2019

Accepted: 14 Oct. 2019

\title{
SELECTING INTER-CITY TRANSPORTATION ROUTES IN COMPLEX TERRAINS USING QUANTITATIVE METHODS - A CASE STUDY FROM NORTHERN YUNNAN, CHINA
}

\begin{abstract}
$A$ variety of factors are involved in inter-city transportation route selection in the areas of complex terrain. With the help of Geographic Information System (GIS), three quantitative methods were employed to determine the transport routes between 44 cities in Northern Yunnan (China), an area with alpine valleys, Karst mountains, and plateau basins. The network analysis in GIS was used to find the routes based on the Transport Suitability Evaluation (TSE) map, which was produced from several factors, including population density, terrain slope, vertical terrain dissection, landslide and mud-flock area, land cover types, and Normalized Difference Vegetation Index (NDVI). Analytic Hierarchy Process (AHP), Grey Relational Analysis (GRA), and Delphi analysis were used to collect and calculate suitability values of these factors. Finally, all the routes connecting 44 cities of Northern Yunnan formed a network which could provide reference for route selection planning in the area.
\end{abstract}

\section{KEY WORDS}

Geographic Information System (GIS); transport route selection; Grey Relational Analysis (GRA); Analytic Hierarchy Process (AHP);

\section{INTRODUCTION}

Transportation plays a major role in the economic development of regions with complex terrains, because the cities in the regions are usually not self-sufficient in energy supply, food demand, as well as available appliance and commuters. For inter-city transport route selection in such areas, it is essential to consider the factors such as distance, suitability, and resistance. These factors include natural elements (e.g. vertical terrain dissection, land cover types, and geological conditions), as well as socioeconomic factors (e.g. population density, level of urbanization, and industry).

Resistance analysis is to determine the path of the least travel cost from the source to the destination. It is a key step in the process of choosing a route in complex terrains. The Grey Relational Analysis (GRA) and Analytic Hierarchy Process (AHP) have been used in various application fields. For example, Palanikumar et al. [1] used GRA for optimizing the parameters of composite material; Ar et al. [2] adopted GRA to evaluate school teaching performance; Hamzacebi et al. [3] employed GRA to determine the stock investments; Camelia et al. [4] used GRA to study the financial sectors in Europe; Kuo et al. [5] used GRA to solve multiple decision-making problems. AHP has been used for site selection of waste landfill, services, solar farms, and wind farms, among others. For example, Shahabi et al. and Yesilnacar et al. [6] combined AHP and satellite images for waste landfill selection in GIS; $\mathrm{Wu}$ et al. [7] conducted site selection for branch banks based on GIS; Uyan [8] used AHP and GIS to find suitable sites for solar farms based on terrain and weather conditions and agricultural facilities. Some examples of AHP in transportation include [9-12]. As far as network analysis is concerned, 
many studies are mainly based on the existing road networks for vehicle route planning, pedestrian walk route planning, and algorithm design for the shortest paths [13-15].

The objective of this study is to identify inter-city transportation routes in complex terrains using quantitative methods in GIS. Unlike some previous studies [13-15] that were based on the existing road networks, this study is based on the resistance evaluation and the shortest distances determined from raster-based analysis. Northern Yunnan (China) is selected as the study area due to its complex terrains and real application potential for future road construction projects. The study area, data, methods, results, and conclusions are described in the following sections.

\section{STUDY AREA AND DATA}

The Jinsha River watershed in Northern Yunnan, China, is used as the study area. The $110,880 \mathrm{~km}^{2}$ study area between $\mathrm{N} 24^{\circ} 30^{\prime} \sim 29^{\circ} 15^{\prime}$ and $\mathrm{E} 98^{\circ} 40^{\prime}$ $\sim 105^{\circ} 15^{\prime}$ is about $28.94 \%$ of the land area of Yunnan Province [16]. It borders Tibet, Sichuan, and Guizhou, and includes 44 cities (Figure 1). The study area is located in the transition region of the first and second steps of China's landform, characterized by mountains and canyons, with mountain area taking up over $90 \%$ of the total area of the Jinsha watershed [17]. The highest elevation in the study area is $5,596 \mathrm{~m}$ and the lowest is $267 \mathrm{~m}$; with $48.2 \%$ of the land having slopes of over $25^{\circ}[18,19]$. The complex terrains have made the transport system a bottleneck for economic development in Northern Yunnan.

The following datasets were used in this study: (1) Landsat 8 Operational Land Imager and Thermal Infrared Sensor (OLI_TIRS) data acquired on October 19, 2015; (2) Digital Elevation Models (DEM) created from 1:50,000 topographic maps; (3) Geo-hazard incidents of every village from 2010 to 2015; and (4) Population data acquired from the Census Data of China 2015 (using village as the statistical unit to generate a raster with a cell size of $5 \times 5 \mathrm{~km}$ ). The Landsat OLI_TIRS data were used to classify the land cover types and to calculate the vegetation coverage with the help of Erdas IMAGINE. With a supervised classification method, the Landsat image was classified into 10 land cover types: water, forest, naked land, scrub-grassland, residential buildings area, paddy field, dry farmland vegetation, glacier, garden field, and alpine meadow. The DEM data were used to generate slope and

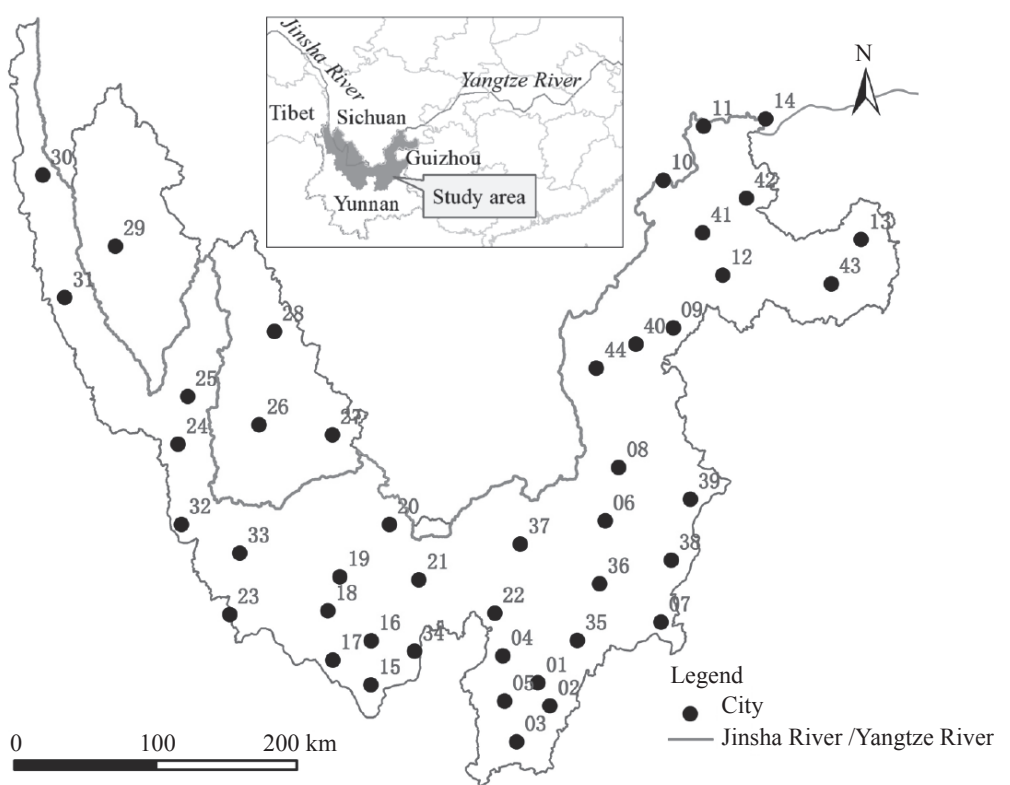

Figure 1 - Location of the Jinsha River watershed in Northern Yunnan, China Note: the Jinsha River is the upper part of the Yangtze River

(01-Kunming, 02-Chenggong, 03-Jinning, 04-Fuming, 05-Anning, 06-Dongchuan, 07-Malong, 08-Huize, 09-Zhaotong, 10-Yongshan, 11-Suijiang, 12-Yiliang, 13-Weixin, 14-Shuifu, 15-Chuxiong, 16-Mouding, 17-Nanhua, 18-Yaoan, 19-Dayao,

20-Yongren, 21-Yuanmou, 22-Wuding, 23-Xiangyun, 24-Heqing, 25-Lijiang, 26-Yongsheng, 27-Huaping, 28-Ninglang, 29-Shangri-la, 30-Deqin, 31-Weixi, 32-Eryuan, 33-Binchuan, 34-Lufeng, 35-Songming, 36-Xunding, 37-Luchuan, 38-Zhanyi, 39-Xuanwei, 40-Ludian, 41-Daguan, 42-Yanjin, 43-Zhenxiong, 44-Qiaojia) 
vertical terrain dissection maps based on a raster cell size of $1 \times 1 \mathrm{~km}$. The geo-hazard statistic data were used to create a geo-hazard spatial distribution map with a raster cell size of $5 \times 5 \mathrm{~km}$ based on the administrative boundary map in ArcGIS.

\section{METHODS}

\subsection{Methodology flowchart}

The transport route selection in this study was based on GRA, AHP, Delphi analysis, and GIS network analysis. Six elements were taken into account in analyzing transport route selection, including population density, vertical terrain dissection, slope, geo-hazard, land cover types, and vegetation coverage. The methodology flowchart is shown in Figure 2. The elements were evaluated based on GRA or Delphi analysis to produce raster layers. All output raster layers were combined to produce a Transport Suitability Evaluation (TSE) map using a cell size of $5 \times 5 \mathrm{~km}$. The TSE map is a raster which shows the cost of building a road that passes through a grid cell, determined by spatial distance and resistance. The spatial distance is the Euclidean distance, and the resistance describes the difficulty of building a transport route passing the area. A transportation route requires maximum transport suitability and minimum spatial distance. Finally, a transport route network was calculated from TSE using network analysis. More details of the methodology are explained in the following sections.

\subsection{Grey Relational Analysis (GRA)}

In the grey system theory, Grey Relational Analysis (GRA) is always employed to study the relationships between different factors. In other words, GRA can be used to obtain the relationships between a reference sequence and all other sequences in a given system, by viewing the reference pattern as the desired goal [20]. Suppose $k$ is the factor to be evaluated, the Grey Relational Coefficient (GRC) $\xi_{i}(k)$ of object $i(1 \leq i \leq n)$ about $k$ (actual value) with respect to $k^{\prime}$ (the best or ideal value of factor $k$ ) is computed as [21]:

$$
\xi_{i}(k)=\frac{\Delta_{\min }+R \Delta_{\max }}{\Delta_{i k}+R \Delta_{\max }}
$$

where $\Delta_{\min }$ is called Two-grade Minimum Difference; $\Delta_{\max }$ is called Two-grade Maximum Difference; $R$ is the discriminative coefficient $(0 \leq R \leq 1)$ and is usually set to $0.5 \cdot \xi_{i}(k) \in[0,1]$. Furthermore,

$\Delta_{\text {min }}=\min _{i=1 . . n} \min _{k}\left|C^{*}(k)-C_{i}^{\prime}(k)\right|$

$\Delta_{\max }=\max _{i=1 . . n} \max _{k}\left|C^{*}(k)-C_{i}^{\prime}(k)\right|$

$\Delta_{i k}=\left|C^{*}(k)-C_{i}^{\prime}(k)\right|$

where $i$ is the index of grid unit; $\xi_{i}(k)$ represents the assessment value of the $i$-th grid unit, i.e. transport suitability evaluation value; $C^{*}(k)$ is the optimal value of $k$ factor; $C_{i}^{\prime}(k)$ is the property value of $k$ factor of the $i$-th unit, such as slope or normalized vegetation index (NDVI). $\xi_{i}(k)$ can also be described as:

$$
\xi_{i}(k)=\frac{\min _{i=1 . . n} \min _{k}\left|C^{*}(k)-C_{i}^{\prime}(k)\right|+R \cdot \max _{i=1 . . n} \max _{k}\left|C^{*}(k)-C_{i}^{\prime}(k)\right|}{\left|C^{*}(k)-C_{i}^{\prime}(k)\right|+R \cdot \max _{i=1 . . n} \max _{k}\left|C^{*}(k)-C_{i}^{\prime}(k)\right|}
$$

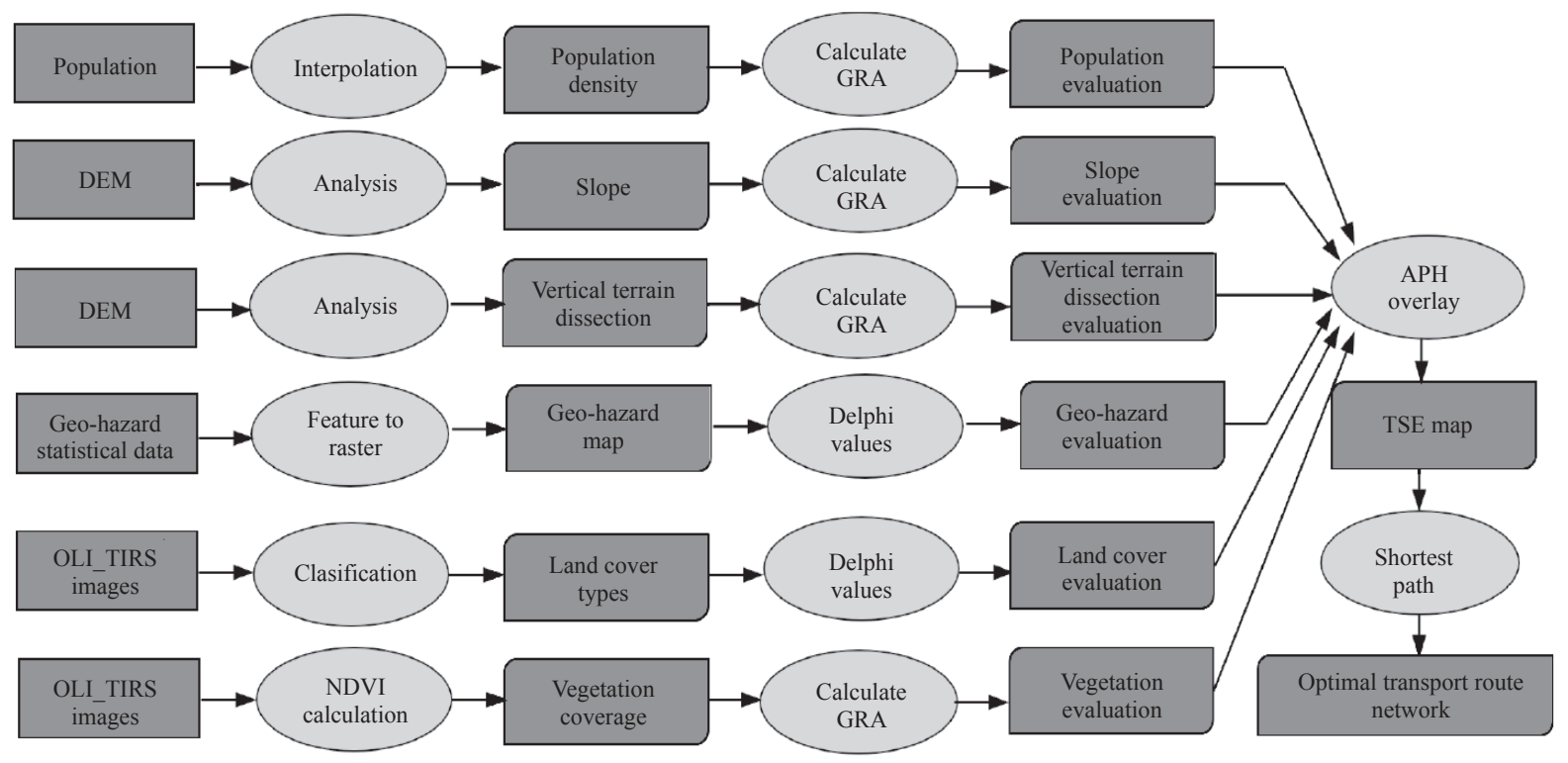

Figure 2-Methodology flowchart 
The factors used in GRA are described below.

Slope. Slope in a Digital Elevation Model (DEM) is the steepest angle of a plane defined by the cell and its eight surrounding neighbours. It is easier to build a road in flat areas than in steep areas, therefore, slope is the most important factor for transport route selection in the study area. The terrain slope raster map was created in ArcGIS based on a 1:50,000 scale DEM in Northern Yunnan, with a maximum slope of $74.4^{\circ}$ and a minimum slope of $0^{\circ}$. Therefore, $C^{*}(k)=0^{\circ}, C_{i}^{\prime}(k)$ is the actual slope value $\left(74.4^{\circ} \sim 0^{\circ}\right), \min _{i} \min _{k}\left|C^{*}(k)-C_{i}^{\prime}(k)\right|=0$; and $\max$ $\max _{k}\left|C^{*}(k)-C_{i}^{\prime}(k)\right|=|0-74.4|=74.4$. Using Equation 5, the slope-based suitability map was obtained.

Vertical terrain dissection. Vertical terrain dissection measures the uneven degree of an area using the difference between the highest and the lowest elevation in a fixed area $(5 \times 5 \mathrm{~km}$ in this study based on the scale of the study area and the topographic features). The highest vertical terrain dissection value is $1,923 \mathrm{~m}$, and the lowest is $0 \mathrm{~m}$ in the study area. A transport resistance map layer based on vertical terrain dissection was created using the same method described for the slope above.

Vegetation coverage. Vegetation coverage reflects the plant density of an area. Usually, the more plant richness of an area, the more difficult it is to select a transport route passing through the area. Normalized Difference Vegetation Index (NDVI) is an important indicator of vegetation coverage. NDVI values were derived from Landsat OLI TIRS images of the study area using the ERDAS IMAGINE software, with a maximum value of 0.78 and a minimum of -1.0. A transport resistance map layer based on NDVI was created using the same method described for the slope above.

\subsection{Delphi analysis}

The Delphi evaluation method is a kind of expert scoring method, or a method based on expert advice. It is mostly used for qualitative evaluation analysis [22-25]. Several qualitative factors in this study cannot be evaluated using GRA due to the lack of quantifiable values, including land cover types and Geo-hazard. These factors were evaluated using the Delphi method which is to obtain the consensus of opinion based on a series of intensive questionnaires for a group of 11 experts, including physical/economic geographers and transportation planners.
Land cover types. There are 10 land cover types in Northern Yunnan. The Delphi method was used to evaluate their suitability for transport, and the following values were obtained - water: 0.1 , forest: 0.2 , naked land: 0.8 , scrub-grassland: 0.7 , residential buildings area: 0.2 , paddy field: 0.9 , dry farmland cultural vegetation: 0.9 , glacier: 0.1 , garden field: 0.8, and alpine meadow: 0.4.

Geo-hazard. According to the historical geo-hazard accidents (landslide, collapse and debris flow) that happened in the area from 2010 to 2015, geo-hazards in Northern Yunnan were divided into three grades: serious, intermediate, and slight. Every village was taken into account in the evaluation process, and the evaluation map was eventually converted into a raster with a cell size of $5 \times 5 \mathrm{~km}$ (Figure 3 ). The results from the Delphi analysis were - serious geo-hazard area: 0.2 , intermediate geo-hazard area: 0.5 , and slight geo-hazard area: 0.8 (Figure 3).

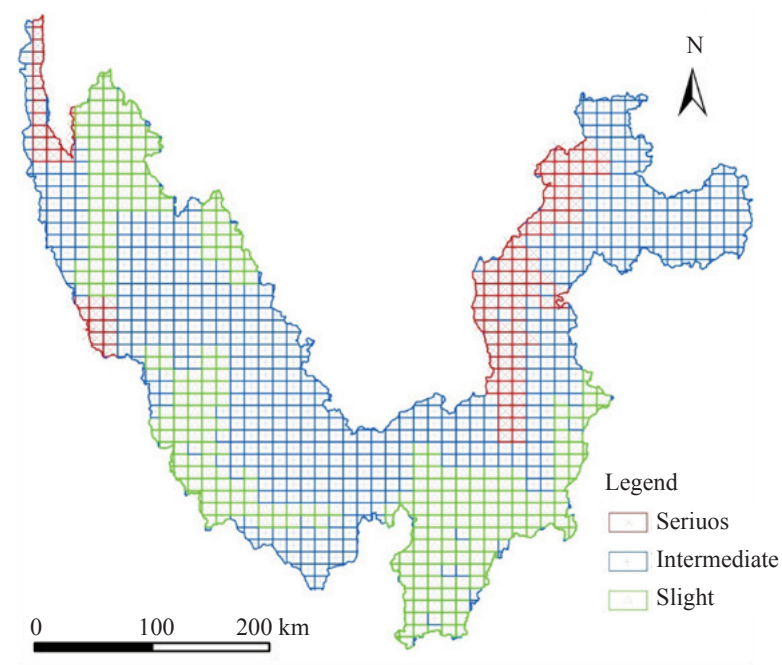

Figure 3 - Geo-hazard grade distribution in Northern Yunnan

\subsection{Analytic Hierarchy Process (AHP) for factor combination}

The influencing factors for transport route selection usually have different weights, and the weights should be determined before the Transport Suitability Evaluation (TSE) map is produced. The Analytic Hierarchy Process (AHP) is an effective way to group these factors. AHP is based on three principles: refraction, comparative judgment, and the synthesis of priorities [26]. Refraction is to put decision-making problems into hierarchical forms. Each factor in the resulting hierarchical structures is 
put in special levels in terms of their origin in higher levels. The synthesis principle refers to the priorities for each site using a determined proportion scale for different levels in a hierarchy, creating priorities for factors at the lower levels of a hierarchy. The major steps of AHP are described below.

\section{Constructing comparative matrix}

This step creates a basic scale with values from 1 to 9 to determine the extent of the relative priorities of two influencing factors (Table 1). To evaluate the resistance of transportation route construction (A of Table 2) for different areas, six factors were taken into consideration, including population density $\left(\mathrm{C}_{1}\right)$, slope $\left(\mathrm{C}_{2}\right)$, vertical terrain dissection $\left(\mathrm{C}_{3}\right)$, geo-hazard $\left(\mathrm{C}_{4}\right)$, land cover type $\left(\mathrm{C}_{5}\right)$, and NDVI $\left(\mathrm{C}_{6}\right)$. The comparative matrix is shown in Table 2.

Table 1 - Binary scale of AHP

\begin{tabular}{||l|c||}
\hline \multicolumn{1}{|c|}{ Definition } & $\begin{array}{c}\text { Value of } \\
\text { importance }\end{array}$ \\
\hline \hline Equal importance & 1 \\
\hline Equal to average importance & 2 \\
\hline Average importance & 3 \\
\hline Average to strong importance & 4 \\
\hline Strong importance & 5 \\
\hline Strong to very strong importance & 6 \\
\hline Very strong importance & 7 \\
\hline Very strong to super strong importance & 8 \\
\hline Super strong importance & 9 \\
\hline
\end{tabular}

Table 2 - AHP comparative matrix of six factors in Northern Yunnan

\begin{tabular}{||c|c|c|c|c|c|c||}
\hline $\mathrm{A}$ & $\mathrm{C}_{1}$ & $\mathrm{C}_{2}$ & $\mathrm{C}_{3}$ & $\mathrm{C}_{4}$ & $\mathrm{C}_{5}$ & $\mathrm{C}_{6}$ \\
\hline \hline $\mathrm{C}_{1}$ & 1 & 2 & 3 & 3 & 5 & 4 \\
\hline $\mathrm{C}_{2}$ & $1 / 2$ & 1 & 2 & 2 & 4 & 3 \\
\hline $\mathrm{C}_{3}$ & $1 / 3$ & $1 / 2$ & 1 & 1 & 3 & 2 \\
\hline $\mathrm{C}_{4}$ & $1 / 3$ & $1 / 2$ & 1 & 1 & 3 & 2 \\
\hline $\mathrm{C}_{5}$ & $1 / 5$ & $1 / 4$ & $1 / 3$ & $1 / 3$ & 1 & $1 / 2$ \\
\hline $\mathrm{C}_{6}$ & $1 / 4$ & $1 / 3$ & $1 / 2$ & $1 / 2$ & 2 & 1 \\
\hline
\end{tabular}

\section{Measuring criterion weight}

a) Calculate the product of every row of the matrix

$$
\begin{aligned}
& M 1=1 \times 2 \times 3 \times 3 \times 5 \times 4=360 \\
& M 2=\frac{1}{2} \times 1 \times 2 \times 2 \times 4 \times 3=24 \\
& M 3=\frac{1}{3} \times \frac{1}{2} \times 1 \times 1 \times 3 \times 2=1 \\
& M 4=\frac{1}{3} \times \frac{1}{2} \times 1 \times 1<\times 3 \times 2=1 \\
& M 5=\frac{1}{5} \times \frac{1}{4} \times \frac{1}{3} \times \frac{1}{3} \times 1 \times \frac{1}{2}=\frac{1}{360} \\
& M 6=\frac{1}{4} \times \frac{1}{3} \times \frac{1}{2} \times \frac{1}{2} \times 2 \times 1=\frac{1}{24}
\end{aligned}
$$

Then calculate the $n$-th root for every $M$ :

$$
\begin{aligned}
& \bar{W}_{1}=\sqrt[6]{M_{1}}=2.67 \\
& \bar{W}_{2}=\sqrt[6]{M_{2}}=1.70 \\
& \bar{W}_{3}=\sqrt[6]{M_{3}}=1 \\
& \bar{W}_{4}=\sqrt[6]{M_{4}}=1 \\
& \bar{W}_{5}=\sqrt[6]{M_{5}}=0.37 \\
& \bar{W}_{6}=\sqrt[6]{M_{6}}=0.59
\end{aligned}
$$

b) Data vectors normalization

For $W=\left[\bar{W}_{1}, \bar{W}_{2}, \bar{W}_{3}, \bar{W}_{4}, \bar{W}_{5}, \bar{W}_{6}\right]^{T}=[2.67,1.70,1.00$, $1.00,0.37,0.59]^{T}$ :

$\sum_{i=1}^{n} \bar{W}_{i}=2.67+1.70+1+1+0.37+0.59=7.33$

$$
\begin{aligned}
& W_{1}=\frac{\overline{W_{1}}}{\sum_{i=1}^{n} \overline{W i}}=\frac{2.67}{7.33}=0.36 \\
& W_{2}=\frac{\overline{W_{2}}}{\sum_{i=1}^{n} \overline{W i}}=\frac{1.70}{7.33}=0.23 \\
& W_{3}=\frac{\overline{W_{3}}}{\sum_{i=1}^{n} \overline{W i}}=\frac{1.00}{7.33}=0.14 \\
& W_{4}=\frac{\bar{W} 4}{\sum_{i=1}^{n} \overline{W i}}=\frac{1.00}{7.33}=0.14 \\
& W_{5}=\frac{\overline{W_{5}}}{\sum_{i=1}^{n} \overline{W_{i}} i}=\frac{0.37}{7.33}=0.05 \\
& W_{6}=\frac{\overline{W_{6}}}{\sum_{i=1}^{n} \overline{W i}_{i}}=\frac{0.59}{7.33}=0.08
\end{aligned}
$$

The resulting feature vector is: $W=[0.36,0.23,0.14$, $0.14,0.05,0.08]^{\mathrm{T}}$

c) Calculate the characteristic root of the judgment matrix $\lambda_{\max }$

$$
A W=\left(\begin{array}{cccccc}
1 & 2 & 3 & 3 & 5 & 4 \\
\frac{1}{2} & 1 & 2 & 2 & 4 & 3 \\
\frac{1}{3} & \frac{1}{2} & 1 & 1 & 3 & 2 \\
\frac{1}{3} & \frac{1}{2} & 1 & 1 & 3 & 2 \\
\frac{1}{5} & \frac{1}{4} & \frac{1}{3} & \frac{1}{3} & 1 & \frac{1}{2} \\
\frac{1}{4} & \frac{1}{3} & \frac{1}{2} & \frac{1}{2} & 2 & 1
\end{array}\right)\left(\begin{array}{l}
0.36 \\
0.23 \\
0.14 \\
0.14 \\
0.05 \\
0.08
\end{array}\right)
$$

$$
\begin{aligned}
& (A W)_{1}=1 \times 0.36+2 \times 0.23+3 \times 0.14+3 \times 0.14+ \\
& +5 \times 0.05+4 \times 0.08=2.23 \\
& (A W)_{2}=\frac{1}{2} \times 0.36+1 \times 0.23+2 \times 0.14+2 \times 0.14+ \\
& +4 \times 0.05+3 \times 0.08=1.41 \\
& (A W)_{3}=\frac{1}{3} \times 0.36+\frac{1}{2} \times 0.23+1 \times 0.14+1 \times 0.14+ \\
& +3 \times 0.05+2 \times 0.08=0.83 \\
& (A W)_{4}=\frac{1}{3} \times 0.36+\frac{1}{2} \times 0.23+1 \times 0.14+1 \times 0.14+ \\
& +3 \times 0.05+2 \times 0.08=0.83
\end{aligned}
$$




$$
\begin{aligned}
& (A W)_{5}=\frac{1}{5} \times 0.36+\frac{1}{4} \times 0.23+\frac{1}{3} \times 0.14+\frac{1}{3} \times 0.14+ \\
& +1 \times 0.05+\frac{1}{2} \times 0.08=0.32 \\
& (A W)_{6}=\frac{1}{4} \times 0.36+\frac{1}{3} \times 0.23+\frac{1}{2} \times 0.14+\frac{1}{2} \times 0.14+ \\
& +2 \times 0.05+1 \times 0.08=0.49 \\
& \lambda_{\max }=\sum_{i=1}^{n} \frac{(A W)_{i}}{n W_{i}}=\frac{(A W)_{1}}{6 W_{1}}+\frac{(A W)_{2}}{6 W_{2}}+\frac{(A W)_{3}}{6 W_{3}}+\frac{(A W)_{4}}{6 W_{4}}+ \\
& +\frac{(A W)_{5}}{6 W_{5}}=6.118
\end{aligned}
$$

Therefore, weight $(W)$ of every factor and its consistency check results are listed below.

$$
\begin{aligned}
& W=\left(\begin{array}{l}
0.417 \\
0.263 \\
0.160 \\
0.062 \\
0.097
\end{array}\right), \quad \lambda_{\max }=6.118, C I=\frac{\lambda_{\max }-n}{n-1}=0.024, \\
& R I=1.24, C R=\frac{C I}{R I}=0.019
\end{aligned}
$$

(Note: when $C R=\frac{C I}{R I}<0.10$, the judgment matrix is considered to have satisfactory consistency.)

Finally, the weights of the factors are determined as - population: 0.36 , slope: 0.23 , vertical terrain dissection: 0.14 , geo-hazard: 0.14 , land cover type: 0.05, and NDVI: 0.08. A Transport Suitability Evaluation (TSE) map with a raster cell of $5 \times 5 \mathrm{~km}$ was created using the weighted overlay of the six factors.

\subsection{Path analysis}

The best transport route always follows the path with small resistance [27-29]. This principle is also the basis for this study. Denoting transport suitability value $S$ as the opposite of the resistance value $R(R=1-S)$, the optimal path of transportation between two cities shall be the one with the smallest resistance and relatively short spatial distance. Figure 4 shows the transport suitability values and the resistance values $(R=1-S)$ between city $\mathrm{X}$ and city $Y$. There are four resistance values: $0.1,0.2,0.4$,

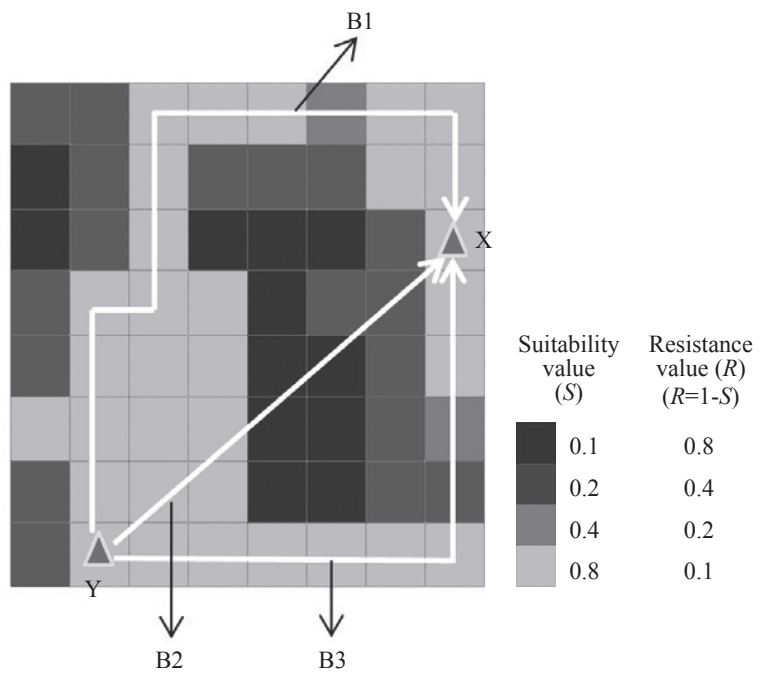

Figure 4 - Schematic diagram of path analysis

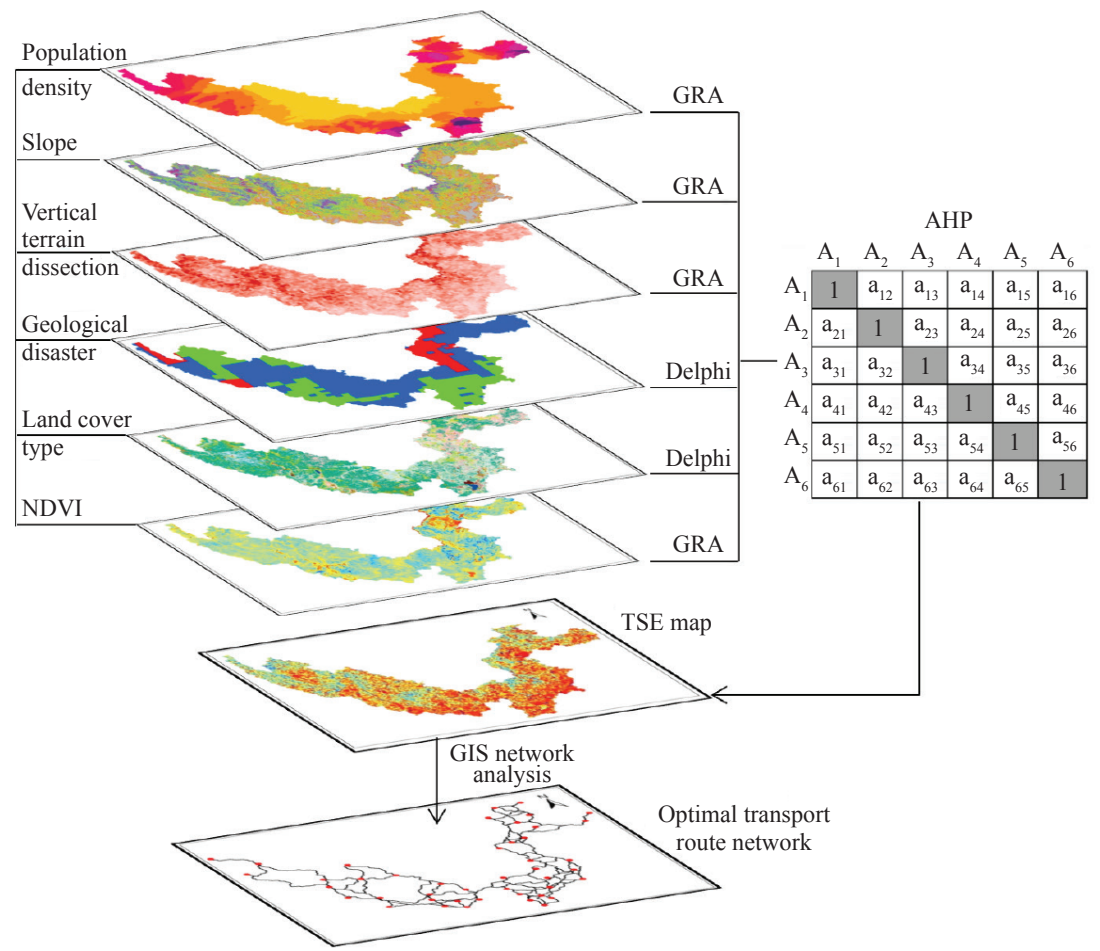

Figure 5 - Building transport route network based on GRA, AHP and GIS 
and 0.8. Suppose there are three paths between the two cities: B1, B2, and B3. The spatial resistance accumulative values of the three paths are 1.4, 1.79, and 1.3 , respectively. B2 is the path with the shortest Euclidean distance but the largest accumulative resistance, while B3 has the smallest accumulative resistance and should be chosen as the transport route. Using this method, a transport suitablity raster map was created using ArcGIS Network Analyst (Figure 5).

\section{RESULT AND DISCUSSION}

Figure 6 shows the inter-city transport route network connecting 44 cities in the study area. The terrain slopes range from $0^{\circ}$ to $5^{\circ}$, and the vertical terrain dissection ranges from 0 to $1,923 \mathrm{~m}$ (in $5 \mathrm{~km}$ by $5 \mathrm{~km}$ windows) over the entire network. The major cover land types are dry farmland cultural vegetation, naked land, scrub-grassland, paddy field, and garden field, while a few routes pass through some residential building areas and alpine meadow areas. No routes pass through water bodies and glaciers.

The above results were compared with the existing highways (2010) in GIS (Figure 7). The results suggest that: (1) highways of category I rarely match the selected routes; (2) about $30 \%$ of category II highways are correlated with the selected routes; and (3) about $50 \%$ of category III highways are correlated with the selected roads. Such differences may be caused by extensive use of tunnels and bridges in Category I highways, while fewer tunnels and bridges are used in Category III highways. Since more Category III highways are needed in the study area, the results in this paper can be used as reference for route selection planning.

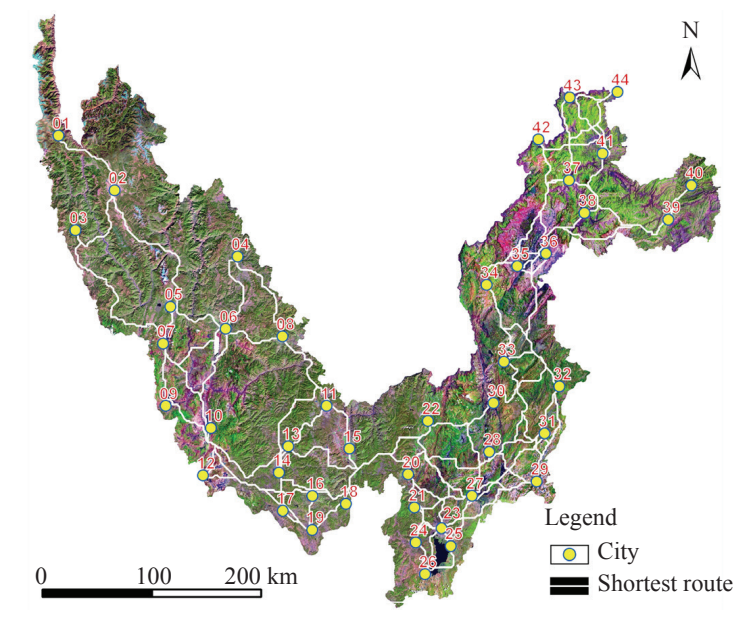

Figure 6-Modelled transport route network in Northern Yunnan

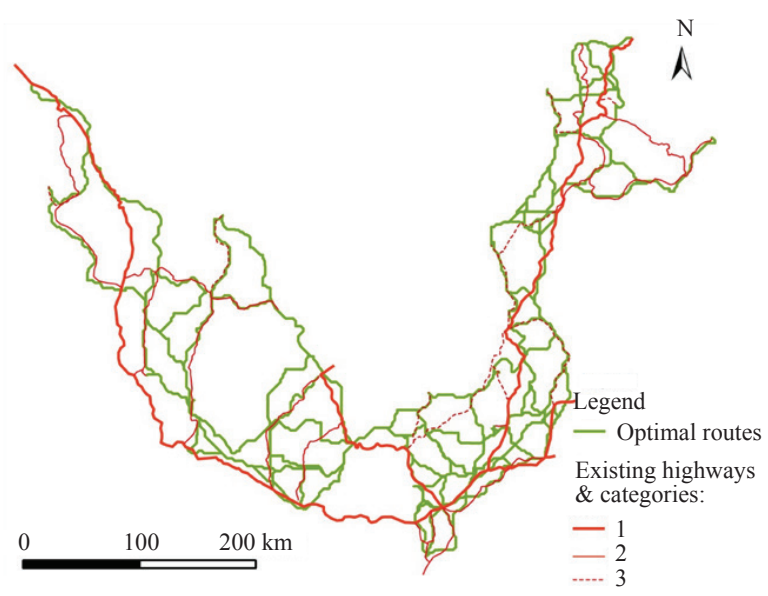

Figure 7 - Existing highways and transport routes identified in this paper

(Highway categories: 1-Expressway; 2-Level 1 and 2 roads; 3-Level 3 and 4 roads, according to the China Highway Classification Standard)

\section{CONCLUSION}

This study used six major factors (population density, slope, vertical terrain dissection, geo-disaster, vegetation coverage, and land cover type) to build the transport route network based on Analytic Hierarchy Process (AHP), Grey Relational Analysis (GRA), and Delphi analysis in Northern Yunnan, China. Among the six factors, the population density and slope are the most important factors affecting the transport route selection in areas of complex terrain. Comparisons with the existing road network suggest that the results are more correlated with Category III highways than with Category I and Category II highways. The relatively low correlation of the results with Category I highways can be explained by the extensive use of tunnels and bridges in complex terrains, while Category III highways are more controlled by the local topography. Therefore, our recommendations are mainly for local government agencies and transportation planners for planning future local roads and modification of the existing roads. While modification of the existing roads in populated areas can be costly, the results from our paper can be used as a reference for planning new roads in remote areas where population distribution is relatively sparse. The study area is also known for frequent geological hazards such as landslides and debris flows. In addition to transportation planning, our results could be potentially used for site selection for relocating villages affected by potential geological hazards, so that relocated residents can have better access to the transportation network. The method 
can be potentially applied to transport route selection in other study areas with the complex terrain. However, it should be noted that the study was carried out in China where private land ownership is very limited. In countries/regions where private land ownership plays an important role in urban/rural planning, the transportation route selection should take into account other factors. In addition to the six factors, the actual route selection is affected by the socioeconomic status and industrial layout of the study area, and further research is needed to incorporate additional factor into the route selection processes.

\section{ACKNOWLEDGEMENTS}

This work was supported by the China Scholarship Council under Grant 201207035006, the National Natural Science Foundation of China under Grant 41161003 and Grant 40901294, and the Plateau Mountain Ecology and Earth's Environment discipline construction project (C176240107).

夏既胜, 董品亮, 赵志芳

\section{复杂地形区城际交通选线的定量方法 - 以中 国云南北部为例 \\ 摘要}

复杂地形区城际交通选线涉及多种因素。本文借 助于地理信息系统，采用了三种定量方法来选取位 于云南北部高山峡谷、喀斯特山地和高原盆地区的 44 个城市之间的交通路线。根据人口密度、地形坡 度、垂直高差、滑坡泥石流分布、土地覆盖类型和 植被指数等因子得出交通适宜性评价图，据此采用 了地理信息系统网络分析方法来寻找最佳路线, 并 采用层次分析、灰色关联分析和德尔菲法选取和计 算这些因子的适宜度。本文所得的连接 44 个城市的 交通路线方案可供研究区交通选线规划时参考。

\section{关键词}

地理信息系统; 交通选线; 灰色

关联分析；层次分析。

\section{REFERENCES}

[1] Palanikumar K, Latha B, Senthilkumar V, Davim J. Analysis on drilling of glass fiber-reinforced polymer (GFRP) composites using grey relational analysis. Materials and Manufacturing Processes. 2012;27: 297-305.

[2] Ar I, Hamzacebi C, Baki B. Business school ranking with grey relational analysis: the case of Turkey. Grey Systems. 2013;3(1): 76-94.

[3] Hamzacebi C, Pekkaya M. Determing of stock investments with grey relational analysis. Expert Systems with Applications. 2011;38: 9186-9195.

[4] Camelia D, Emil S, Cotfas L. Grey relational analysis of the financial sector in Europe. The Journal of Grey
System. 2013;25(4): 19-30.

[5] Kuo Y, Yang T, Huang G. The use of grey relational analysis in solving multiple attribute decision-making problems. Computers \& Industrial Engineering. 2008;55: 80-93.

[6] Shahabi H, Keihanfard S. Evaluating Boolean, AHP and WLC methods for the selection of waste landfill sites using GIS and satellite images. Environment Earth Science. 2014;71: 4221-4233.

[7] Wu J, Chen J, Ren Y. GIS enabled service site selection: Environmental analysis and beyond. Information System Front. 2011;13: 337-348.

[8] Uyan M. GIS-based solar farms site selection using analytic hierarchy process (AHP) in Karapinar region, Konya/Turkey. Renewable and Sustainable Energe Reviews. 2013;28: 11-17.

[9] Islam R, Saaty T. The analytic hierarchy process in the transportation sector. Proceedings of the $19^{\text {th }}$ international conference on multiple criteria decision making, 7-12 January 2008, Auckland, New Zealand; 2008. p. 79-91.

[10] Zoran D, Saša M, Dragi P. Application of the AHP method for selection of a transportation system in mine planning. Underground Mining Engineering. 2011;19: 93-99.

[11] Baric D, Starcevic M. Implementation of analytic hierarchy process in solving transport problems. International Journal of the Analytic Hierarchy Process. 2015;07: 12-21.

[12] Hamurcu M, Eren T. Transportation planning with analytic hierarchy process and goal programming. International Advanced Researches and Engineering Journal. 2018;02: 092-097.

[13] Xie K, Deng K, Shang S, Zhou X, Zheng K. Finding alternative shortest paths in spatial networks. ACM Transactions on Database System. 2012;37(4): 1-30.

[14] Peng M, Xiong N, Park J, Vasilakos A, Zhang J. The weighted shortest path search based on multi-agents in mobile GIS management services. Wireless Communications and Mobile Computing. 2012;12: 302-317.

[15] Han J, Zhao Y, Dai K. The approach for shortest paths in fire succor based on component GIS technology. In: Gong P, Liu Y. (eds.) Geoinformatics 2007: Geospatial Information Technology and Applications, Proc. of SPIE, Vol. 6754; 2007. Article ID 67543M.

[16] Xia J, Yang S, Wang Y, Zhao X. Study on landscape pattern feature and its change in North Yunan(Yunnan part). Research of Soil and Water Conservation. 2008;15(4): 152-156.

[17] Xia J, Yang S, Wang Y, Zeng H. Study on spatial distribution of ecological potential based on GIS in North Yunan (Yunnan part). Resources and Environment in the Yangtze Basin. 2009;18(9): 865-870.

[18] Xia J, Yang S, Wang Y, Liu C. Distribution patterns of vegetation index based on ArcGIS in the middle sect of North Yunan. Bulletin of Science and Technology. 2010;26(3): 325-330.

[19] Mao R, Meng G, Zhou Y. Study on prevention and control of soil and water loss in Jinsha River Basin of Yunnan province. Research of Soil and Water Conservation. 2006;13(1): 184-185.

[20] Hu Y. Neighborhood-based collaborative filtering using grey relational analysis. The Journal of Grey System. 
2014;26(1): 99-115.

[21] Wei G. GRA method for multiple attribute decision making with incomplete weight information in intuitionistic fuzzy setting. Knowledge-Based Systems. 2010;23(3): 243-247.

[22] Musa H, Yacob M, Abdullah A, Ishak M. Delphi method of developing environmental well-being indicators for the evaluation of urban sustainability in Malaysia. Procedia Environmental Sciences. 2015;30: 244-249.

[23] Coleman S, Hurley S, Koliba C, Zia A. Crowdsourced Delphis: Designing solutions to complex environmental problems with broad stakeholder participation. Global Environmental Change. 2017;45: 111-123.

[24] Di Zio S, Castillo Rosas J, Lamelza L. Real time spatial Delphi: fast convergence of experts' opinions on the territory. Technological Forecasting \& Social Change. 2017;115: 143-154.

[25] Krigsholm P, Zavialova S, Riekkinen K, Ståhle P, Vii- tanen K. Understanding the future of the Finnish cadastral system - A Delphi study. Land Use Policy. 2017;68: 133-140.

[26] Saaty T. Decision making with the analytic hierarchy process. Int J Serv Sci. 2008;1(1): 83-98.

[27] Atkinson D, Deadman P, Dudycha D, Traynor S. Multi-criteria evaluation and least cost path analysis for an arctic all-weather road. Applied Geography. 2005;25: 287-307.

[28] Choi Y, Park H, Sunwoo C, Clarke K. Multi-criteria evaluation and least-cost path analysis for optimal haulage routing of dump trucks in large scale open-pit mines. International Journal of Geographical Information Science. 2009;23: 1541-1567.

[29] Choi Y, Nieto A. Optimal haulage routing of off-road dump trucks in construction and mining sites using Google Earth and a modified least-cost path algorithm. Automation in Construction. 2011;20: 982-997. 